Early Modern Jesuit Writing of History as an Inspiration for Central European Historians before 1773

Author: Jakub Zouhar

Source: Engaging Sources: The Tradition and Future of Collecting History in the Society of Jesus (Proceedings of the Symposium held at Boston College, June 11-13, 2019)

Edited by: Cristiano Casalini, Emanuele Colombo, and Seth Meehan

ISBN: 978-1-947617-09-4

Published by: Institute of Jesuit Sources

Originally Published: April 20, 2021

https://doi.org/10.51238/ISJS.2019.23

Provided in Open Access by the Institute for Advanced Jesuit Studies at Boston College.

The Institute of Jesuit Sources, specializes in preserving, maintaining, and expanding for scholars around the world important texts and studies in Jesuit history, spirituality, and pedagogy.

Visit our website at https://jesuitsources.bc.edu 


\title{
Early Modern Jesuit Writing of History as an Inspiration for Central European Historians before 1773
}

\author{
JAKUB ZOUHAR ${ }^{1}$
}

\section{Introduction}

The phenomenon of early modern Jesuit historiography and its influence on other scholars in central Europe is of wider than regional importance. Nevertheless, the history of Jesuit scholarship in the central and east central European region has still not been widely studied compared with other regions largely due to the languagesPolish, Czech, Slovak, Hungarian, and German - in which many books, accounts, treatises, papers, and academic theses have been written. ${ }^{2}$ Historical scholarship was undoubtedly a key element of Jesuit literary culture in all of Europe, particularly in the seventeenth century. However, it played a particularly important role in east central Europe - including the Habsburg realm (Hungary included), Bavaria, and Poland - given the broader context of the twin threats posed by Turkey and the Protestant Reformation.

\footnotetext{
${ }^{1}$ I thank Seth Meehan and Amanda Bennett, who proofread my draft with great diligence. All mistakes in this paper are my own and cannot be attributed to my proofreaders.

${ }^{2}$ This remains true even though articles on the Jesuit historiography in Bohemia, Hungary, Poland etc. have recently been published. See Ivo Cerman, "Jesuit Historiography in Bohemia," in Jesuit Historiography Online, ed. Robert A. Maryks, June 2017; http://dx.doi.org/10.1163/24687723_jho_COM_192532 (accessed April 1, 2021); Béla Vilmos Mihalik, "Centuries of Resumptions: The Historiography of the Jesuits in Hungary," in Jesuit Historiography Online, ed. Robert A. Maryks, December 2016; http://dx.doi.org/10.1163/2468-7723 jho_COM_192543 (accessed April 1, 2021); and Stanisław Obirek, "The Historiography on Early Modern Jesuits in Poland," in Jesuit Historiography Online, ed. Robert A. Maryks, October 2017; http://dx.doi.org/10.1163/2468-7723 jho_SIM_192569 (accessed April 1, 2021). Obirek's account is not an overview of pre-suppression Jesuit historiography but an outline of historiography focusing on the Jesuits in Poland before 1773. For further information on the Society of Jesus in the early modern Polish-Lithuanian Commonwealth, see Marceli Kosman and Andrea Mariani, "Jesuits in the Early Modern Polish-Lithuanian State: Recent Trends and Research Directions," Archivum historicum Societatis Iesu 86, no. 171 (2017): 145-208. The text also focuses on the modern historiography of the Jesuits in Poland before 1773, not on the Jesuits living in the sixteenth to eighteenth centuries and writing treatises on history. The same is true for the essay by Liudas Jovaiša, "Jesuit Historiography in Lithuania since 1990: Proximity and Distance along World Routes," Archivum historicum Societatis Iesu 85, no. 169 (2016): 221-32.
}

https://doi.org/10.51238/ISJS.2019.23

(C) Institute of Jesuit Sources, 2021 


\section{Historical Background to the Work of the Jesuits in Central and East Central Europe}

Although the Jesuits cooperated in the Counter-Reformation after 1620 within the Habsburg realm, their role was subordinated not only to the interests of the church but also to those of the state. Jesuit scholars nevertheless played a key role in scholarship across central and east central Europe until the order's dissolution in $1773 .^{3}$ Their enemies, of course, blamed them for unfair practice, accused them of spreading treason through education, and even charged them with the destruction of whole universities (specifically those of Ingolstadt, Prague, ${ }^{4}$ and Vienna). After 1814, when a new era for the order began, the Jesuits' role in the historical scholarship of central and east central Europe was much weaker than before 1773. Yet an antiJesuit ideology nonetheless persisted.

By the sixteenth century, central and east central Europe had been severely affected by both the Reformation and the Counter-Reformation. The most complicated conditions were undoubtedly in the Czech lands ${ }^{5}$ that were affected by the spread of Martin Luther's teaching. Hungary, on other hand, which was linked with the Czech lands by means of a personal union, had a different problem: the Turkish attacks in the Balkans. As a result, the Holy See and its subordinated authorities allowed a multi-confessional space to be established in the Czech lands and later in Hungary. The pope had a powerful ally, as the House of Habsburg then ruled in Spain, the Holy Roman Empire, and the Habsburg realm, including all of central and east central Europe. Ferdinand I (r.1526-64) focused intensely on the religious affairs of the individual countries making up his empire, which included the Czech lands, Austria, and Hungary. He based the restoration of the Roman Catholic faith in his empire on the papal nuncios (from 1577 on the nuncios resided in Prague); the new or reformed religious orders, primarily the Jesuits, who came to Prague in 1555; and re-establishing the Prague archbishopric (1560). ${ }^{6}$ The Jesuit order

\footnotetext{
${ }^{3}$ See Paul J. Shore, The Eagle and the Cross: Jesuits in Late Baroque Prague (St. Louis, MO: Institute of Jesuit Sources, 2002). Czech historiography (see the review by Jiří Havlík, Acta Universitatis Carolinae: Historia Universitatis Caroliniae Pragensis 43, nos. 1-2 [2003]: 255-60) praised the main part of the book. However, Havlík criticizes Shore for an ignorance of Czech literature of the 1930s and of the 1960s, as well as for incorrect and confusing chapters dealing with the historical background from 1556 to 1750 .

${ }^{4}$ In Prague, it was the other way around. The Jesuits founded a residence for poor students that became a model for other universities, such as that of Parma. See Paul F. Grendler, The Jesuits and Italian Universities 1548-1773 (Washington, DC: Catholic University of America Press, 2017), 163.

5 "The Czech lands" or "the Bohemian lands" are the three historical regions of Bohemia, Moravia, and Czech Silesia. In a historical context, it is any territory ruled by the kings of Bohemia (i.e., the lands of the Bohemian crown as established by Emperor Charles IV [r.1346-78] in the fourteenth century).

${ }^{6}$ See Alena Richterová and Ivana Čornejová, The Jesuits and the Clementinum (Prague: NK, 2006).
} 
quickly spread all over the country, but an independent province of Bohemia was not founded until 1623. In 1623-1723, 2,286 Jesuits were based in the province. ${ }^{7}$

The Society of Jesus came to Hungary in 1561 at the invitation of the archbishop of Esztergom, Miklós Oláh (1493-1568). The Jesuits eventually put down roots in Hungary as strong as those in the Czech lands, though their situation was much tougher than that of their Bohemian colleagues owing to the Turks and plague. As early as the end of the sixteenth century, they were able to establish more colleges in the parts of the country that were under Christian control. Yet the reign of Calvinist princes in the seventeenth century remained a greater obstacle. Ottoman Hungary was a missionary territory throughout the seventeenth century, and the residences became a solid foundation for the growth of the Society of Jesus in a liberated Hungary. ${ }^{8}$ After 1700 , famous historians came from the province of Austria, which was founded ${ }^{9}$ in 1563 and also included Hungary.

The history of the Jesuit presence in Poland began when the order's members first came to the country in 1564 . They were mostly regarded as foreigners, as Spanish defenders of the Habsburg absolute monarchy, much like the municipal governments in the Apennine Peninsula and Sicily; ${ }^{10}$ however, the Catholic nobility supported the Jesuits until 1773. Still, their influence in the field of historiography was much weaker than in the Czech lands, where the Bohemian provincial, Johann Zwicker, signed a deed in Prague on October 13, 1728 stating that history should be a mandatory subject of schooling within the Bohemian Jesuit province. ${ }^{11}$

Taking the above into account, it is clear that Jesuit historians exercised the most influence in Bohemian, Moravian, and Silesian historiography within central and east central Europe. Accordingly, the next section of this paper will focus primarily on this region.

\footnotetext{
${ }^{7}$ Ivana Čornejová, "Jezuitský řád v Čechách v době Balbínově," in Bohuslav Balbín a kultura jeho doby, ed. Zuzana Pokorná and Martin Svatoš (Prague: PNP, 1992), 23-32; see also Shore, Eagle and the Cross, 75.

${ }^{8}$ After 1526, the army of the Ottoman Empire conquered large parts of the Kingdom of Hungary. The liberation of Hungary lasted almost two hundred years. In 1718, the entire Kingdom of Hungary was removed from Ottoman rule.

${ }^{9}$ It had split from the Upper German province and in 1623 was divided into the Austrian province and the Bohemian province centered in Prague.

${ }^{10}$ Grendler, Jesuits and Italian Universities, 90.

${ }^{11}$ See Bernhard Duhr, S.J., Die Studienordnung der Gesellschaft Jesu (Freiburg: Herder, 1896), 106.
} 


\section{Jesuit Historiography of the Seventeenth and Eighteenth Century in East Cen- tral Europe}

East central Europe had had a strong medieval historiography, but the humanistic historical scholarship of the fifteenth and sixteenth centuries differed greatly from one region to the next. Poland, for instance, welcomed humanistic scholars to the University of Kraków throughout the fifteenth century. In contrast, the turbulent Czech lands were late to accept the Renaissance and humanism because of the Hussite Wars (1419-34) and the major political and social changes that followedindeed, even in the seventeenth century, the most reliable source of information about the Czech lands for Western scholars remained the Historia Bohemica by Enea Silvio Piccolomini (Pope Pius II [r.1458-64]). ${ }^{12}$ Another source of information was the Bohemian Chronicle of Václav Hájek of Libočany (d.1553), originally written in Czech (1533-39, in print 1541) but faithfully translated into German in 1596/98. This book combines detailed and often highly erudite scholarship with incorrect fragments of information. The third work that reported on the history of the Czech lands to the West was the Historiae regni Bohemiae libri XXXIII (Thirty-three books on a history of the Kingdom of Bohemia [1552]) of Jan Skála of Doubravka (Dubravius [1486-1553]), who was the bishop of Olomouc and an outstanding humanist. Yet his work was ultimately based on Hájek, Piccolomini, and several other Bohemian chroniclers.

The transition from humanism to baroque in the Czech lands was slow and uneasy. The Battle of the White Mountain (November 8, 1620) destroyed Bohemia's political autonomy and changed the lands culturally. Numerous local humanists fled north, to Saxony, Franconia, and even farther afield. The situation began to change in the 1770s when more and more lay intellectuals from the ranks of the nobility sought to write about Bohemian culture, language, and history.

\section{Jesuit Historiography in the Czech Lands: Bohuslav Balbín, His "School," and His Legacy}

Most historians focusing on the history of Bohemia, Moravia, and Silesia came from the Czech lands. However, there were also exceptions. One such exception was Giulio Soliman, S.J. (1595-1639), ${ }^{13}$ who was born in the Apennine Peninsula

\footnotetext{
${ }^{12}$ In English, see František Šmahel, "Enea Silvio Piccolomini and His Historia Bohemica," in Enea Silvio Piccolomini, Historia Bohemica, ed. Dana Martínková, Alena Hadravová, and Jiř́i Matl (Prague: KLP, 1998), liii-xcvii.

${ }^{13}$ See Jitka Křesálková, "Giulio Solimano a Praha," in Baroko v Itálii: Baroko v Čechách = Barocco in Italia, barocco in Boemia: Setkáváni osobností, ideji a uměleckých forem, ed. Vilém Herold and
} 
and wrote several accounts of Bohemian history. His declared intention in doing so was to educate the youth about Bohemian history and provide models they could emulate. His most significant published works focusing on the history of the Czech lands are as follows: Bohemia exoriens, gentilis, christiana, pia, bellicosa, regnans, imperans, austriaca, Ferdinando III. concinnata sub nomine Collegii Pragensis Societas Jesu (Arising, pagan, Christian, pious, warlike, reigning, ruling, Austrian Bohemia [Prague, 1627]); Elogia ducum, regum, interregum, qui Bohemis praefuerunt (Eloges of princes, kings, and viceroys that ruled Bohemia [Prague, 1629, 2nd ed., 1673]); and Oratio de S. Norberto, de S. Wenceslao (Speech on St. Norbert and St. Wenceslas [Prague, 1627]).

The Considerationes (Considerations) ${ }^{14}$ of Belgium-born Jacob de la Haies, S.J. (1615-82), who lived in the east Bohemian Hostinné estate for a long time, shows that the non-Bohemian, Moravian, and Silesian Jesuits also paid attention to contemporary issues. De la Haies was shaken by the local conditions in which some noblemen allegedly lived contra sensum communem theologorum et praxim proborum (against the common meaning of theology and an orderly life).

The key figure in Jesuit historiography in the Czech lands was Bohuslav (Bohuslaus) Balbín, S.J. (1621-88), who not only wrote many historical treatises on local as well as ecclesiastical topics but also persuaded many of his friends (both Jesuits and non-Jesuits) to do so too. Not all Jesuits, however, were keen on studying history or helping Balbín with his works. ${ }^{15}$ Strongly influenced by Hájek's chronicle, Balbín decided to describe the history, mythology, geography, geology, flora and fauna of the Czech lands in a "more veracious" account. He knew the works of various Bohemian as well as Western historians, ${ }^{16}$ and even non-Catholics (e.g., Pavel Stránský and Christian Weis). Balbín's book Bohemia sancta (Holy Bohemia $)^{17}$ was directly inspired by the four-volume work of Matthäus Rader, S.J. (1561-1634), entitled Bavaria sancta et pia (Holy and pious Bavaria [Munich, 1615-28, 2nd ed. 1704]). All his works are the result of extensive study of historical sources in the Bohemian, Moravian, Silesian, Austrian, and probably also

\footnotetext{
Jaroslav Pánek (Prague: Filosofia, 2003), 389-403 (in Czech), 315-28 (in Italian). See also Bohuslav Balbín, Bohemia docta, ed. Raphaele Ungar (Prague: J. A. Hagen, 1778), pars 2, 81-82.

${ }^{14}$ The treatise is based on the Jesuit scholars Hermann Bausebaum (Medullae Theologiae moralis), Francisco Suárez, Vincento Fillucci, and Paul Laymann.

${ }^{15}$ One example for all was Father Friedrich Bridel, S.J. (1619-80), a friend of Balbín and a famous poet. From 1656 to 1660, he led the printing office of the Jesuits in the Prague Clementinum, but he was always deaf to all of Balbín's calls. It is not clear why from the preserved correspondence.

${ }^{16}$ Balbín knew the work of Roberto Bellarmino, S.J. and Jacob Gretser, S.J. (Caesar Baronius), whose writing he recommended. See Antonín Rejzek, S.J., P. Bohuslav Balbín T.J. Jeho život a práce (Prague: Dědictví sv. Prokopa, 1908), passim.

${ }^{17}$ Liber hagiographicus or Bohemia sancta sive De sanctis Bohemiae, Moraviae, Silesiae, Lusatiae (Prague, 1682). See Jiřr Šitler, "Svaté Čechy Bohuslava Balbína," in Bohuslav Balbín a kultura jeho doby v Čechách, ed. Zuzana Pokorná and Martin Svatoš (Prague: PNP, 1992), 40-45.
} 
Hungarian archives, which were not open to the public at the time, ${ }^{18}$ because, as he once wrote, Nemo enim potest historiam scribere sine documentis (Nobody is able to write on history without sources). It is hardly surprising, therefore, that Balbín was repeatedly appointed to the office of historiographer of Jesuit houses (historicus domus, collegii) and of the Bohemian province (scriptor Historiae nostrae provinciae) as a whole in 1662-71 and 1679-88(?). ${ }^{19}$ Yet no matter how much Balbín loved the order, he did not enjoy writing about Jesuit history ${ }^{20}$ and preferred to focus on the Landesgeschichte (provincial history), a subject in which he was considered an expert.

\section{Historians Profoundly Influenced by Balbín}

One of Balbín's friends, Georg Crugerius, S.J. (1608-71), edited a historical calendar, Sacri pulveres (Holy dust [1667-1767]), ${ }^{21}$ "which tells life stories of important saints, affiliates each of them with a month of the year, and associates them with events of Bohemian history in a similar manner as Balbín did."22 Yet Balbín criticized the layout of his work - it was too complicated and thus unclear. Crugerius's first published work was a treatise (1656-59) on Marian piety and places of pilgrimage issued within Balbín's work Diva montis sancti (Holy mount). ${ }^{23}$ We know from his correspondence with Balbín that both historians cooperated very closely, ${ }^{24}$ were dissatisfied with their posts, and sometimes felt alone in their work. Their situation must have been even worse at those moments when they did not understand each other in precise points of their research. Whereas Crugerius, for instance,

\footnotetext{
${ }^{18}$ Balbín claimed he had visited all the bigger towns in the Czech lands and ninety-six castles.

${ }^{19}$ Based on the triennial catalogs, one can prove the historiographical activity of more than 250 Jesuits within the Bohemian province. It is only possible to link individual persons to individual texts in the case of the histories of the provinces and most of the provincial annals; in the case of annual reports and other texts written in colleges, it is not possible to identify the authors.

${ }^{20} \mathrm{He}$ complained to the Jesuit superior general in Rome about it several times. His documented manuscripts on Jesuit history are as follow: (1) Historia collegii S.J. Pragensis ad S. Clementem 1555-1610, 1618 et 1620 (parts); (2) Elogia defunctorum in Societatis ab anno 1669 (parts); (3) Elogia nostrorum in provincia Bohemiae defunctorum (1627-1686) (small parts); (4) Historia collegii Jiczinensis; (5) Historia provinciae Bohemiae (parts).

${ }^{21}$ Georg Crugerius, Sacri pulveres mensis [...], 10 vols. (Prague, 1667-76). Crugerius himself wrote the months January to August; September was prepared for printing in 1672 by an unknown scholar, most likely Wenzel Schüttl, S.J. (1639-83); October (1676) was published in Prague by an unknown scholar; and the last two months were edited by Balbín but published by Jan Giranek, S.J. (1761) and Michael Krammer, S.J. (1767) respectively.

${ }^{22}$ Cerman, "Jesuit Historiography in Bohemia."

23 "Affectus Beatissimae Virginis Mariae in Bohemiam, Moraviam et Silesiam et affectus gentis Bohemae erga Matrem Dei," in Bohuslav Balbín, Diva montis sancti (Prague, 1666), 42-58.

${ }^{24}$ See Crugerius's letter to Balbín, dated February 15, 1645. Published by Rejzek, P. Bohuslav Balbín, 367.
} 
claimed that the noble house of Guttstein was not of Slavic origin, Balbín ${ }^{25}$ praised it as "Czech, not German." ${ }^{26}$ Both historians also disagreed about the authorship of a medieval manuscript entitled Mariale Arnesti (Mariology of Ernest of Pardubice). Whereas Balbín, based on in-depth research, believed that the first Prague archbishop Ernest of Pardubice (1297-1364) had not been involved in the manuscript, Crugerius was confident of his authorship.

Tomáš Pešina of Čechorod (1629-80), vicar general in spiritualibus (in spiritual affairs) of the Prague archbishop and chapter dean of St. Vitus cathedral in Prague, was not a Jesuit, yet he studied at the Jesuit schools and the order's members were his friends, particularly Balbín and Crugerius. Having been invited to do so by Balbín, Pešina worked on a history of Moravia entitled Prodromus Moravographiae (The predecessor of a history of Moravia [Litomyšl, 1663]), ${ }^{27}$ which is composed in Czech though it has a Latin title. His main work, Mars Moravicus (The Mars in Moravia [1677]), which is in Latin and based largely on Hájek's and Skála's chronicles, describes wars in Moravia from medieval times to 1526. Balbín supervised Pešina and made him known to other historians. Balbín also said that he did not know of anyone as skilled in dealing with history as Pešina. ${ }^{28}$ Like Balbín, Pešina lavished most of his praise on the period of Great Moravia (833-c.907) and of Charles IV (r.1346-78), yet the two authors differed in their views of the Hussite movement (c.1419-34).

Jan Tanner, S.J. (1623-94), with whom Balbín actively collaborated, also deserves mention. ${ }^{29}$ Balbín asked Tanner to give him all of the materials that he had about the Holy Mount near Př́bram; in exchange, he offered to help Tanner with his biography of Albrecht Chanovský, S.J. (1581-1643), ${ }^{30}$ a highly successful missionary operating in southwest Bohemia in the first half of the seventeenth century. As well as sending Tanner (1661) sources about the noble house of Sternberg ${ }^{31}$ and

\footnotetext{
25 Bohuslav Balbín, Origines [...] comitum de Guttenstein, ubi refertur vita B. Hroznatae [...] (Prague, 1665).

26 The letter of December 10, 1665 in which Balbín wrote to Crugerius about the matter was published by Rejzek, P. Bohuslav Balbin, 196-97.

${ }^{27}$ His most famous work is undoubtedly a small piece entitled Ucalegon Germaniae, Italiae et Poloniae: Hungaria, flamma belli Turcici ardens (Prague, 1663). It is an entreaty addressed to Europe in order to stop all armed conflicts among various countries and to focus entirely on the Turks.

${ }^{28}$ Balbín, Bohemia docta, pars 2, 95.

29 Jan Malura, "Jan Tanner," in Lexikon české literatury, ed. Luboš Merhaut et al. (Prague: Academia, 2008), 4:part 1, 844-46, cit. 845. Balbín wrote to Tanner about history as early as the $1650 \mathrm{~s}$.

${ }^{30}$ Joannes Tanner, Vir apostolicus seu Vita et virtutes R.P. Alberti Chanowski (Cologne, 1660, in Czech 1680).

${ }^{31}$ Balbín told Tanner about a quarrel about the antiquity of the noble house of Sternberg and of Wallenstein. Tanner eventually published two genealogical accounts: Amphitheatrum gloriae spectaculis leonum Waldsteiniorum adornatum (1661) and Vestigia virtutis et notabilis Sternbergicae (1661, in German 1723).
} 
charters of the period of Georg of Poděbrady, Balbín also proofread Chanovský's biography. ${ }^{32}$ Tanner is most famous for two works-Via sancta Praga VeteroBoleslaviam (The holy way from the old town of Prague to Stará Boleslav [1679 in Czech, 1680 in German, 1690 in Latin]), and the history of the city of Plzeň, preserved in a manuscript entitled Historia urbis Plsnae (The history of the town of Plzeň [edited and translated into German in 1835]).

The Jesuit Jan Kořínek (1626-80) was also influenced by Balbín. Having joined the order at the age of fifteen, he later became a rector of the Jesuit college at Litoměřice (1666-69), where he first met Balbín. ${ }^{33}$ Kořínek wrote several philosophical treatises, but he is most well known for his history of the town of Kutná Hora, Staré paméti kutnohorské (The ancient history of Kutná Hora), which was written in Czech and published in $1675 .{ }^{34}$ Divided into twenty chapters including the history of the town from its origins until 1614, the work is strongly influenced by Balbín's approach to the writing of history, Czech language nationalism, and of course Catholicism. His history was intended for the general public and was consequently compiled without annotations. Surprisingly, he was not appointed as a historian of any Jesuit house or college.

Alois Jan Hackenschmidt, OPraem (1626-83), ${ }^{35}$ also belonged to the network of historians under the leadership of Balbín. Hackenschmidt first met Balbín in the summer of 1642 and maintained a close relationship with him until his death. ${ }^{36}$ Hackenschmidt is the author of many works that describe the histories of monasteries (e.g., Teplá monastery) in the form of annals written in Latin. While Hackenschmidt's main work was entitled Miscellanea ${ }^{37}$ in honor of Balbín's Miscellanea, the two works are fundamentally different. Whereas Balbín's masterpiece

\footnotetext{
32 Balbín improved this biography by advising Tanner to add marginal notes in order to enable readers to verify the facts. Despite this improvement, the biography approximates to the hagiographical genre.

${ }^{33}$ See Kořínek's letter to Balbín dated May 23, 1674, Kutná Hora, quoted by Balbín, Bohemia docta, pars 2, 21 .

${ }^{34}$ See a modern textual critical edition, Jan Kořínek, Staré paměti kutnohorské, ed. Alexandr Stich and Radek Lunga (Prague: NLN, 2000), 605pp.

${ }^{35}$ Jana Oppeltová, "P. Aloysius a s. Balbino: Život a dílo Aloise Jana Hackenschmidta, tepelského analisty a prítele Bohuslava Balbína," Acta Universitatis Carolinae: Historia Universitatis Carolinae Pragensis 50, no. 1 (2010/11): 85-98.

${ }^{36}$ Their mutual correspondence written in Latin has been edited. See Adolf Patera, ed., "Dopisy Bohuslava Balbína k opatu tepelskému Raimundu Wilfertovi I. a knězi téhož kláštera Aloisovi Hackenschmidtu z let 1664-1667," Věstník Královské české společnosti nauk 1888 (Prague, 1888): 143-226; Ondřej Podavka, "Vzájemná korespondence Bohuslava Balbína a Aloise Hackenschmidta z let 1664-1667," Listy filologické 136, nos. 1-2 (2013): 161-88; Podavka, "Z korespondence Bohuslava Balbína s Aloisem Hackenschmidtem z let 1664-1667," in Délám to $k$ větši slávě Boži a chvále vlasti: Bohuslav Balbín a jeho doba; barokní jezuitské Klatovy 2014, 92-114; Zuzana Adamaitis, "Amice in Christo Honorandissime [...] Ke korespondenci Aloise Hackenschmidta a Bohuslava Balbína," in Manu propria: Sborník přispěvků $k$ životnímu jubileu PhDr. Aleny Richterové, CSc., ed. Zuzana Adamaitis (Prague: NK, 2012), 67-89.

${ }^{37}$ Miscellanea I-XI (1667-81) are preserved at Státní okresní archiv Cheb (State Regional Archives at the Town of Cheb), Collection: Premonstráti Teplá, book nos. 28-37.
} 
has a very clear conception, Hackenschmidt wrote down many notes and pieces of information with the intent of composing a compact work in the foreseeable future, which he never managed to complete.

Another of Balbín's friends was Maximilian Rudolph Schleinitz (1605$75),{ }^{38}$ the first bishop of Litoměřice (1655-75), who was more of an ecclesiastical dignitary and well-educated nobleman than a scholar or historian, as is apparent from his historical text Vandalo-Bohemia sive De Bohemiae modernae Vandalicae familiarumque ejusdem ad nostram usque memoriam (The Vandals in Bohemia or what we now know on the Vandals in Bohemia). The work was often used by Bohemian historians in the seventeenth and eighteenth centuries, yet it was ultimately based on the author's assumptions without any analytical work with historical sources. Balbín had initially spoken highly of Schleinitz's work, ${ }^{39}$ but after reading the final version the Jesuit realized that it was of no value for historiography. ${ }^{40}$ For that reason, Schleinitz forbade its publication.

Balbín and Crugerius served as a repository of knowledge for historian Jan František Beckowsky, O.Cr. (1658-1725), ${ }^{41}$ who wrote about fifty historical and theological accounts. His main historical work ${ }^{42}$ is based on the Bohemian Chronicle of Hájek, which Beckowsky wanted to correct and update, but he also used other historical sources, including those produced by Jesuit historians.

\section{Historians Indirectly Influenced by Balbín}

Balbín also had an indirect influence on other scholars, predominantly lesserknown Jesuits (e.g., Melichor Guttwirth, Johann Klausal, Johann Kisling, and Bernardin Erber) who wrote texts on history and cited Balbín in their works.

Balbín was also a repository of knowledge for two main historians of the Bohemian province. The earlier-born of them was Johann Miller, S.J. (1650-1723), originally from Silesia, who became the provincial superior (November 25, 1703December 26, 1707), the rector of the University of Prague from January 14, 1708 to November 7, 1711, and the fortieth rector of the University of Olomouc from

\footnotetext{
38 Johann Evangelista Schlenz, Maxmilian Rudolf Freiherr von Schleinitz und seine Zeit (Warnsdorf: n.p., 1914).

${ }^{39}$ Bohuslav Balbín, Epitome historica Rerum bohemicarum (Prague, 1677), 146.

${ }^{40}$ Balbín, Miscellanea, I, 2 (Prague, 1680).

${ }^{41}$ The Knights of the Cross with the Red Star or Military Order of the Crusaders of the Red Star (in Czech Křižovnický řád rytírư s červenou hvězdou; in German Kreuzherren mit dem Roten Stern; in Latin Ordo Militaris Crucigerorum cum Rubea Stella, Canonici Regulares Sanctissimae Crucis a stella rubea, Crucigeri cum rubea stella, Crucigeri stellati, Stelliferi) is a religious order originating from Bohemia, devoted mainly to offering medical care.

42 Poselkyně starých př́běhưv českých aneb Kronika česká I (Prague, 1700); Poselkyně starých př́běhưv českých II (Od roku 1526-1715), ed. Antonín Rezek, vol. 1 (1526-1607), vol. 2 (16081624), vol. 3 (1625-1715) (Prague: Dědictví sv. Prokopa, 1879-80).
} 
December 17, 1711 to February 24, 1715. He is most well known for his history of the Bohemian province, which has never been printed. ${ }^{43}$ His work also dealt with the history of the Jesuit colleges within the Bohemian province ${ }^{44}$ and the Virgin Mary of Kłodzko, ${ }^{45}$ Cheb, and Bohosudov (Mariaschein), all of which are reminiscent of similar works produced by Balbín.

Johann Schmidl, S.J. (1693-1762), a native of Brno, also wrote a history of the Bohemian province. Having had no other duties, he worked on the history from 1742 to his death. Unlike Miller, Schmidl managed to publish his work in print. ${ }^{46}$ His work is built up in chronological order, while Miller's history is divided into thematic groups. Both Balbín and Miller served him as sources of information, though the latter more so than the former. However, Balbín is nevertheless mentioned in his history many times, including the preface.

Historian Franz Pubitschka, S.J. $(1722-1807)^{47}$ was one of the last Jesuit scholars to have been indirectly influenced by Balbín. At the beginning of 1766/67, he worked in the headquarters of the Bohemian Jesuit province, at the Clementinum in Prague, as the last historiographer of the province before 1773. We have no information about where, when, or how concretely he became acquainted with Balbín's work. Yet we know without any doubt that his masterpiece was intended to be a resumption of Balbín's work. It was an ambitious ten-volume chronological history of Bohemia entitled Chronologische Geschichte Böhmens unter den Slaven (A chronological history of the Czech lands in the Slavic period [Prague and Leipzig, 1770-1801]), numbering over 5,360 pages and published in German, albeit written in Latin. Pubitschka mentioned Balbín a hundred times in his texts and confessed his admiration for him in the preface.

\footnotetext{
${ }^{43}$ Historia provinciae Bohemiae Societatis Iesu ab anno 1555 usque ad annum 1723 (MS found in the National Library of the Czech Republic, Prague, sign. XXIII C 104).

${ }^{44}$ Benefactores collegii et templi Iglavinesi (MS found in MZA Brno, Cerr. II, no. 51); Epitome historiae collegii S.J. Egrae (MS found in MZA Brno, Cerr. II., no. 281), see also his Egra sancta (Cheb, 1694); Historia collegii Hradistensis S.J. (MS found in MZA Brno, Cerr. II, no. 282); or Copia rerum memorabilium collegii et domus primae probationis Brunae (MS found in MZA Brno, Cerr. II, no. 305).

${ }^{45}$ Historia beatissimae Virginis Glacenis (Glaz, 1690). There is also a German translation of the work.

${ }^{46}$ Historiae Societatis Jesu provinciae Bohemiae, 1550 ad 1663, 4 vols. (Prague, 1747-59).

${ }^{47}$ Jakub Zouhar, František Pubička S.I. (1722-1807): Barokni historik ve století rozumu (Červený Kostelec: P. Mervart, 2014); Zouhar, "Pubitschka, Franz (1722-1807)," in BiographischBibliographisches Kirchenlexikon (2013), 34:cols. 1157-62; http://www.bbkl.de/p/pubitschka_f.shtml (accessed April 18, 2021). In English, see Shore, Eagle and the Cross, 196-98.
} 


\section{Jesuit Historiography in the Kingdom of Hungary}

Historiography was embedded in the work of the Hungarian members of the Society of Jesus, as Paul J. Shore has shown. ${ }^{48}$ The center of historical scholarship of the Hungarian Jesuits was in Upper Hungary (the present-day Slovak Republic), in the city of Trnava (in Latin Tyrnavia; in Hungarian Nagyszombat). The city was home of the Trnava University, the only university in the Kingdom of Hungary at the time, which was founded on May 12, 1635 by Archbishop Péter Pázmán. Until 1770 , the university was fully under the control of the Jesuits, who created a school of history there, a cradle from which several Jesuits spread their historical thought out across the whole of Europe. In doing so, they were seeking to recreate the critical historical research conducted by scholars in seventeenth-century western Europe. However, although there were attributes common to the Western scholars and the Hungarian Jesuits, such as emphasizing the value of authentic historical sources and their analysis, the works of the Hungarian Jesuits are mostly far from being critical by present standards. The Hungarian Jesuits emphasized patriotism and studied not only church but also political history.

Sacred or ecclesiastical history was the field of scholarship for Martin Cseles, S.J. (Čeleš [1641-1709]), 49 "a Hungarian Cicero," who because of his historical work ${ }^{50}$ had trouble with his superiors. ${ }^{51}$ His collaborator was Gabor Hevenesi, S.J. (1656-1715), ${ }^{52}$ who has been regarded as a co-founder of "Hungarian scientific historiography" $" 53$ and the author of the Ungariae sanctitatis indicia, sive Brevis quinquaginta sanctorum et beatorum memoria (The history of saints in Hungary or a brief treatise on fifty saints and blessed men and women [Trnava, 1692, 2nd ed. 1737]), including fifty profiles of the saints and a list of 213 of their names, as well as beatified men and women connected to Hungary. The same topic of sacred

\footnotetext{
${ }^{48}$ Paul J. Shore, Narratives of Adversity: Jesuits in the Eastern Peripheries of the Habsburg Realms (1640-1773) (Budapest: Central European University Press, 2012), 211-41.

${ }^{49}$ Paul J. Shore, "Martinus Cseles, S.J., Brother Julianus, and the Rediscovery of Magna Hungaria," in A Divided Hungary in Europe: Exchanges, Networks and Representations, 1541-1699, ed. Gábor Almási et al. (Cambridge: Cambridge Scholars Publishing, 2014), 1:183-99.

${ }^{50}$ Elucidatio historico-chronologica de episcopatu Transylvaniae (Rome, 1702); a biography Decennium Georgii Szécsényi metropolitae Strigoniensis (Trnava, 1721), and the eleven-volume Thesaurus bullarum brevium ecclesiae Hungaricae iura privilegia historiam spectantia (1705), and Descriptio amplitudinis episcopatus Sirmiensis (1707).

${ }^{51}$ For the problems connected to his research, see Shore, Narratives of Adversity, 226-30.

52 Jozef Šimončič, "Gabriel Heveneši a jeho projekt výskumu uhorských dejín," Viera a život 18, no. 3 (2008): 66-71. The project, or invitation, entitled Modus materiae conquirendae pro Annalibus ecclesiasticis regni Hungariae continuandis (before 1694), is found in the Collectio Kaprinaiana, Egyetemi Könyvtár, Budapest, B, 42:212-26.

${ }^{53}$ Malovecká, Karol Wagner, 22-23. He also tried to claim that the third superior general of the Society of Jesus, Francisco de Borja (in office 1565-72), had Hungarian ancestry. See Shore, Narratives of Adversity, 217.
} 
history also interested Carol Péterffy, S.J. (1700-46), ${ }^{54}$ a native of present-day Bratislava, and Carol Wagner, S.J. (1732-90), ${ }^{55}$ who was distinguished by his objective attitude to topics and his combination of various parts of historical scholarship, such as diplomatics, genealogy, historical geography, and epigraphy. ${ }^{56}$ Alexander Söréni, S.J. (Szörényi [1664-1719]), ${ }^{57}$ born in Nitra, and Nicolas Schmidt, S.J. (also known as Fabri [1707-67]) ${ }^{58}$ are also noteworthy since their works were well known among European scholars. Jan Príleský, S.J. (1709-90), a nobleman by origin, belonged among the great admirers of the Holy Virgin. ${ }^{59}$ There was another member of the Society who occupied a pre-eminent position among Jesuit historians, namely György Pray, S.J. (1723-1801). ${ }^{60} \mathrm{He}$ is well known as the first person to discover the so-called Pray's Codex (Halotti beszéd), the first historical document written entirely in the Hungarian language (around 1200). ${ }^{61}$ Having lived in the country, he knew the Kingdom of Hungary very well, as is reflected in his texts. ${ }^{62}$ Pray rediscovered the manuscripts with historical accounts by Gabor

\footnotetext{
${ }^{54}$ His work Sacra concilia ecclesiae romano-catholicae in regno Hungariae celebrata ab anno Christi 1016 usque ad annum 17152 vols. (n.p. [Poland], 1741-42) is based on Hevenesi's research in the archives as well as libraries in Hungary and Rome. It has been in use since the eighteenth century. ${ }^{55}$ Shore, Narratives of Adversity, 231-32. Wagner is the only Hungarian Jesuit who has his "own" modern biography, namely Malovecká, Karol Wagner.

${ }^{56}$ His most important works are Analecta Scepusii sacri et profani 4 vols. (Vienna, 1773-78); the critical edition of the correspondence of 1490-98 of Archbishop Petrus Váradi, Petri de Warda [...] Epistolae (Bratislava-Košice, 1776), Diplomatarium comitatus Sárosiensis [...] (Bratislava-Košice, 1780), or in the manuscript preserved account Praelati, barones, magnates, officiales, praepositi, abbates regni Hungariae diplomatibus ab anno 1001-1748 subscripsit.

${ }^{57}$ Propilaeum bibliothecae Universitatis Graecensis, quo scriptores hic quondam seu discentes seu docentes eorumque opera recensentur (Graz, 1703), Nova series Pontificum Romanorum et archiepiscoporum Strigoniensium ab a. 1000 ad a. 1717 (Trnava, 1717), and in the preserved manuscript preserved Pannonia docta (found in the library Országos Széchenyi Könyvtár, Budapest, Kézirattár fol. Lat. 156).

${ }^{58}$ Imperatores Ottomanici a capta Constantinopoli, 9 vols. (Tyrnaviae, 1747-51). Other works are: Palatini regni Hungariae (Tyrnaviae, 1739); Archiepiscopi Strigoniensis compedio dati (Tyrnaviae, 1752, 2nd ed. 1758); and Episcopi Agrienses (Tyrnaviae, 1763).

${ }^{59}$ Historia Mariana brevi metro concinnata (Košice, 1733); Leonisi papae congnomento Magni opera omnia (Tyrnaviae, 1766), and Acta sanctorum Hungariae, 2 vols. (Trnava, 1743-44).

${ }^{60}$ No modern biography of Pray exits. In English, see Orsolya Báthory, "György Pray's Unpublished Manuscript: Epitome rerum sub Josepho II., Leopoldo II. et Francisco I. regibus Hungariae gestarum," Classica mediaevalia Neolatina 3 (2009): 407-17.

${ }^{61}$ This funeral sermon includes around 190 Hungarian words. See László Meszey, "Probleme der Entstehungsgeschichte des Pray-Kodex," in Armarium, 23-40.

${ }^{62}$ Selection: Annales veteres Hunnorum Avarorum et Hungarorum, 210 ad 997 (Budapest, 1761); Annales regum Hungariae. 997 ad 1564, 5 vols. (Budapest, 1763-70); still valuable Dissertatio historico-critica de prioratu Auranae (Vienna, 1773); Synodus sub Laurentio Strigoniensi archiepiscopo celebrata, ex codice mss. seculi XII. exeuntis (Bratislava-Košice, 1777); Descriptio decimae pontificiae in dioecesi Veszprimiensi seculi XI. ex codice mss. tabularii secreti Vaticani (Bratislava-Košice, 1777) based on the documents from the Secret Vatican Archives; and finally, Specimen Hierarchiae: Hungaricae complectens seriem chronologicam archiepiscoporum et episcoporum Hungariae cum rudi dioecesium delineatione adjectis, si quae sunt peculiares, preaerogativis, ut plurimum ex diplomatibus congestum, 2 vols. (Bratislava-Košice, 1776, 1779); Historia regum Hungariae stirpis Austriacae (Budapest, 1799).
} 
Hevenesi and Stephan Kaprinai, ${ }^{63}$ and he urged their transport to the university library at Buda, which he directed, thus saving them for future generations. It has been claimed that he was the first Jesuit in Hungary to write about history as his primary occupation. ${ }^{64}$ Pray was patronized not by his order, but by the Hungarian Estates.

\section{Jesuit Historiography in Poland}

As a result of the political and social circumstances in the Polish-Lithuanian Commonwealth (1648-1764), a period of economic and social decline, ecclesiastic historiography in the country experienced a grave crisis. ${ }^{65}$ Hence the historiography of the Society of Jesus was of a poor quality, and there are only a limited number of historiographical works. ${ }^{66}$ Despite this, the Jesuits shaped Polish religious thinking and cultural attitudes and created a highly effective educational system.

The history of the professed house in Kraków was compiled by Jan Wielewicki, S.J. (1566-1639), ${ }^{67}$ prefect of the colleges in Kraków, Lviv, Poznan, and Kalisz, and from 1622 on procurator of the order in Rome. Wojciech Wijuk Kojałowicz, S.J. (1609-77) was devoted to the history of Lithuania. His Historiae Lithuanae, ${ }^{68}$ which is regarded as one of the most important studies of the history of the region from the mid-seventeenth century, was used as the main source for Lithuanian history for over two hundred years. He is also the author of more than twenty other works, including Herbarz rycerstwa Wielkiego Księstwa Litewskiego

\footnotetext{
${ }^{63}$ His collection includes over three hundred manuscripts with texts written by the Jesuits such as Schmidt and Johann Korneli, S.J. (1686-1748). Kaprinai cooperated with the Protestants too. The collection also incorporates a set of excerpts by Franz Foriš-Otrokoci (1648-1718), an evangelic and Calvinist preacher who later converted to Catholicism.

${ }^{64}$ Hölvényi, Ungarische Jesuiten, 184.

65 "Polska," in Encyklopedia katolicka (2011), 15:cols. 1162-1298; Kazimierz Puchowski, Edukacja historyczna w jezuickich kolegiach Rzeczypospolitej 1565-1773 (Gdańsk: Wydawnictwo Uniwersytetu Gdańskiego, 1999).

${ }^{66}$ See Ludwik Grzebień, S.J., ed., Encyklopedia wiedzy o jezuitach na ziemiach Polski i Litwy (Kraków: WAM, 2004 [1996]). Michał Piotr Boym, S.J. (c.1614-59) was not a historian in the real sense of the word because he was, first and foremost, a missionary to China. Franciszek Bohomolec h. Bogoria, S.J. (1720-84) was a dramatist, linguist, and theatrical reformer, yet his critical edition of Polish historiographical works entitled Zbior dziejopisów polskich (includes the chronicle of Marcin Bielski, 1764; the chronicle of Maciej Stryjkowski, 1766; the chronicle of Marcin Kromer, 1767; and Aleksandr Gwagnin's chronicle of Sarmatism in Europe, 1768) is of great importance to Polish historiography in many respects.

${ }^{67}$ Historici diarii domus professae Societate Jesu Cracoviensis 1579-1639 (MS, ed. in 4 vols., 1881-99).

${ }^{68}$ Historiae Lithuanae pars prior, de rebus Lithuanorum ante susceptam Christianam religionem conjunctionemque [...] cum regno Poloniae (Gdańsk, 1650) and Historiae Lituaniae a conjunctione Magni Ducatus cum Regno Poloniae (Antwerp, 1669).
} 
(An armorial of knights of the Grand Duchy of Lithuania) ${ }^{69}$ and Miscellanea rerum ad statum ecclesiasticum in Magno Ducatu Lithuaniae pertinentia (Miscellanea of ecclesiastical affairs in the Grand Duchy of Lithuania [1650]).

Jan Kwiatkiewicz, S.J. (1629-1703), professor of philosophy, theology, and mathematics in Jesuit schools with contacts in Prague, published a monumental ecclesiastical history beginning in $1198 .^{70}$ Yet the work has been of greater importance for the history of the Polish language than for ecclesiastical historiography.

The compilation Facies Rerum Sarmaticarum (The nature of Sarmatism) ${ }^{71}$ by Adam Ignacy Naramowski, S.J. (1686-1736) is also of a poor quality from the viewpoint of methodology and accuracy.

Kaspar Niesiecki, S.J. (1682-1744) was the author of the ten-volume Herbarz Polski (The Polish armorial [Lwów, 1728-1845]), which was also written in the Polish language. The work obeys all world-standards of genealogy according to modern Polish historiography.

Polish history was one of the hobbies of Szymon Majchrowicz, S.J. (171783), called "the Polish Bossuet." His main historical work was the four-volume Trwała szczęśliwość królestw, albo ich smutny upadek, wolnym narodom przed oczy stawiona na utrzymanie nieoszacowanej szczęśliwości swojej cz (A permanent deterioration of the kingdom or its woeful decline [Lviv, 1764; 2nd ed., Kalisz, 1783]), which influenced the historiography of Sarmatism (or Sarmatianism) and of Messianism in the early nineteenth century.

Franciszek Rzepnicki, S.J. (1710-80), ${ }^{72}$ archivist (1766 to 1771) of the Jesuit province seated in Kraków, was an author of a catalog of all Polish and Lithuanian archbishops up to $1760 .^{73}$ Based predominantly on printed sources, the work was also compiled thanks to Jesuit and civic manuscripts and deeds. He not only wrote biographies of the church dignitaries but also described histories of the archbishoprics and the archdioceses.

\footnotetext{
${ }^{69}$ The English translation of both volumes is as follows: An Armorial of the Knighthood of the Grand Duchy of Lithuania Which Is Called COMPENDIUM, in Which the Coats of Arms or Heraldry of the Noble Families of the Grand Duchy of Lithuania are Explored (1897) and An Armorial of the Nobility of the Grand Duchy of Lithuania Which Is Called NOMENCLATOR (1905).

${ }^{70}$ Roczne dzieje kościelne od roku Pańskiego 1198 aż do lat naszych (Kalisz, 1695).

${ }^{71}$ In Facie Regni Poloniae, Magniq[ue] Ducatus Litvaniae gestarum, vols. 1 and 2 (Vilnius, 1724, 1726).

${ }^{72} \mathrm{He}$ also translated Jesuit accounts of missionaries from Latin into Polish: Historię prześladowania wiary chrześcijańskiej w Japonii [...] (1763); Joseph de Jouvancy, Historię o pomnożeniu wiary chrześcijańskiej w państwach chińskich [...] (1765). See Andrzej Paweł Bieś, "Rzepnicki, Franciszek," in Encyklopedia katolicka (Lublin: KUL, 2012), 17:cols. 734-35.

${ }^{73}$ Vitae praesulum Poloniae et Magni Ducatus Lithuaniae res praecipuae illorum temporibus gestae ad annum 17603 vols. (Poznań, 1761-63). The work was partly re-published in Jacek Wiesiołowski, Katalogi biskupów poznańskich (Poznań: Wyd. Miejskie, 2004), 91-173.
} 
Nikodem Muśnicki, S.J. (1765-1805) was a historian of the order in Russia, chiefly in Belarus. From 1781 onward, he studied and later taught in the college at Polotsk, since the Jesuits were not suppressed in Russia after 1773. Unfortunately, his history, Historia Societatis Jesu Rossiacae, conservatae in Alba Russia et propagatae (A history of the Society of Jesus in Russia, maintained and propagated in Belarus), has not yet been published.

Adam Stanisław Naruszewicz, S.J. (1733-96), ${ }^{74}$ a noble by origin, was the first modern historian to write a history of the Polish nation. ${ }^{75}$ His history of Poland, which covers the period from its origins until 1386, is influenced by the Enlightenment: its author did not admit myths and legends as a historical source, and he was also critical of the church. As a professor of rhetoric at the Collegium Nobilium in Warsaw in 1762-72, he became friends with the Polish king Stanisław August Poniatowski (r.1764-95), who appointed him as a royal historiographer. Naruszewicz wrote poetry, historical treatises, translations, dramas, and commentaries aimed at the general public.

\section{Instead of a Conclusion: Allure of the Society of Jesus in Central and East Central Europe}

From the above summary of historical documents dealing with the religious situation in sixteenth- to eighteenth-century central and east central Europe, it is clear that the Society of Jesus, a new religious order, influenced several older ones rooted in the medieval period. How was this possible? At first sight and focusing primarily on the Jesuits, no straight answer can be given to this question. We must instead concern ourselves with other religious orders within the region.

The Dominicans, for instance, the long-term ideological enemies of the Jesuits in the region, were severely affected by regional wars and the threat posed by the Turks, ${ }^{76}$ and even though members of the Order of Preachers had repeatedly been humiliated by the Jesuits - among other things, the Jesuits played a role in preventing Dominicans from teaching at various universities - they nevertheless

\footnotetext{
74 Andrzej Feliks Grabski, Dzieje historiografii (Poznań: WP, 2011), 404-6; Edward Alfred Mierzwa, Historia historiografii t. 2: Renesans-Oswiecenie (Warsaw, 2007), 643-44.

${ }^{75}$ Historie narodu polskiego, 2-7 vols. (Warsaw, 1780-86, vol. 1, ed. 1824).

${ }^{76}$ For the Czech lands, see Jakub Zouhar, Česká dominikánská provincie v raném novověku (14351790) (Prague: Krystal OP, 2010); in English, Zouhar, Cyrill Riga O.P. (1689-1758): The Life and Work of a European Preacher in the Age of Reason (Rome: Agelicum University Press, 2015), 3147; for Hungary and Austria, see Viliam Štefan Dóci, O.P., Die Seelsorgliche Tätigkeit der Kaschauer Predigerbrüder: Ein Dominikanerkonvent im Ambiente von Pfarrei, Stadt und Staat im 18. Jahrhundert, Quellen und Forschungen zur Geschichte des Dominikanerordens, Neue Folge, Bd. 23 (Berlin: De Gruyter, 2018).
} 
admired the Society's historiographical works. ${ }^{77}$ Balbín and Crugerius were their examples up until the eighteenth century.

The Cistercians seem to have been in even the worse trouble than the Dominicans. The only true historian of the Cistercian order in the Czech lands was Augustin Sartorius, O.Cist. (1663-1723), ${ }^{78}$ the author of the history of his order. ${ }^{79}$ The work was spread across Europe, from France to Hungary. He also knew the Jesuit historians of the seventeenth century.

The relationship between the Jesuits and the Premonstratensians in Bohemia and Moravia has been documented by Hackenschmidt. And what about the Benedictines, the oldest religious order in the West? The Benedictines, no doubt, have left behind a rich historiographical tradition since the sixth century, and central and east central Europe is no exception. ${ }^{80}$ Balbín and Crugerius were historical sources for Benedictine historians in the Czech lands, ${ }^{81}$ as mentioned previously. Even in eighteenth-century Bohemia, the Jesuits were considered a more reputable religious order than the Benedictines; the proof for this is that Franz Joseph Count Kinsky, the highest chancellor of Bohemia, asked the Jesuits on behalf of Maria Theresa to establish a new noble academy in Prague. Only when they refused to participate in the project did Kinsky ask the Benedictines in $1743 .{ }^{82}$

That the Society of Jesus formed the intellectual elite of the Czech lands including until 1773 is not surprising. Moreover, the Habsburgs, the Viennese court, and the majority of the aristocracy of the Austrian realm gave their full support to the Jesuits. Like almost all rulers at the time, the Habsburgs believed that religious division threatened the security of the state, and the Jesuits seemed to guarantee its integrity. Further, the Jesuits in the seventeenth-century Czech lands acted independently: they were a law unto themselves and were often admonished by the Roman curia, as well as the superior general of the order in the period from the $1630 \mathrm{~s}$ to the $1650 \mathrm{~s}$. Among members of the religious orders, the Jesuits had most understanding for the policy of absolutistic rulers who used the Society until the second half of the eighteenth century, when they had so much political power

\footnotetext{
77 The opinion is based on my own research into Dominican historiography.

78 See Anett Matl, “'Zum immerwährenden süssen Andenken des lieben Alterthums': Die barockisierung des böhmischen Klosters Ossegg am Beginn des 18. Jahrhunderts," in Mitteleuropäische Klöster der Barockzeit: Vergangenwärtigung monastischer Vergangenheit in Wort und Bild, ed. Markwart Herzog and Huberta Weigl (Konstanz: UVK, 2011), 367-86, esp. 381-84.

${ }^{79}$ Cistercium Bisternium [...] historia elogias (Prague, 1700, in German Prague, 1708).

${ }^{80}$ What follows is based on my own research; see Jakub Zouhar, "Přehled benediktinského dějepisectví v českých zemích,” Konštantinove listy/Constantine’s Letters 9, no. 2 (2016): 39-73.

${ }^{81}$ In Hungary, the monks did not write history until the nineteenth century. In Bavaria and Austria, the Jesuits were not sources for the monks but their rivals. The Benedictines in Poland were in a poor condition in the sixteenth and seventeenth centuries, and the new Polish congregation was not founded until 1709.

82 The academy, Collegium regium Mariae Theresiae, however, was never founded due to economic and political problems.
} 
that they could survive without them. This understanding was based on the fact that the Jesuits in the Czech lands and, to a lesser extent in Bavaria, Austria, and Hungary, grew apart from the medieval conception of the church and began to approximate the ideology of new absolutistic states. It is no coincidence that the Jesuits would appeal various decisions to the rulers and the administration of the states, not to the Holy See. And finally, by contrast to the Dominicans until the 1680s, up until 1773 most of the Jesuits of the Bohemian province were educated, lived, and died in the province in which they were born. ${ }^{83}$

Now it is hopefully easier to answer the question, which is why the Society of Jesus was so sought-after by talented young men throughout the sixteenth to eighteenth centuries in the Czech lands, the country where non-Catholics still represented the vast majority of the population by the mid-sixteenth century. The Jesuits became the propagators of the Catholic faith there after 1620 as well as playing an important role in education and combating the plague. ${ }^{84}$ Within the region of east central Europe, their schools were regarded as the best in the seventeenth century.

The final question to ask is how it was possible that the narrative defined by Jesuit historians even influenced non-Catholic scholars. Research on intellectual history in early modern Europe has shown that scholars in the classics and history started to remove the differences between confessions within Christianity from the second half of the seventeenth century onward. The scholars started to adopt scientific attitudes and a new methodology, and they encouraged themselves to be more open-minded toward new ideas. In the Czech lands particularly, several members of the Society of Jesus pushed the new methodology and thereby influenced others.

The Jesuits of the sixteenth to eighteenth centuries worked on their books, accounts, and treatises focusing on history with limited material resources. Yet the works that several generations of the Jesuits composed at such great cost were and still are of use in many ways. In their own context, they served as useful tools and models of how to prepare scholarly works in premodern Europe. They also demonstrated the existence of large and rich remains of a past scholarly system, where the knowledge, ideals, and working methods of their authors are clearly visible. The story of Jesuit historical scholarship thus tells us a great deal about the thinking of "the former elite" 85 and its mental landscape.

\footnotetext{
${ }^{83}$ It is also true in the case of Italian Jesuits. See Grendler, Jesuits and the Italian Universities, 90.

${ }^{84}$ Karel Černý and Sonia Horn, eds., Plague between Prague \& Vienna: Medicine and Infectious Diseases in Early Modern Central Europe (Prague: Academia, 2018).

${ }^{85}$ This label was given to the pre-suppression Jesuits by Jaroslav Šotola in his PhD thesis, "Zrušení jezuitského řádu v českých zemích. Kolektivní biografie bývalé elity (1773-1800)” (PhD diss., University of Prague, 2005); https://is.cuni.cz/webapps/zzp/detail/64701/?lang=en (accessed April 19, 2021).
} 